CASE 2

A 72 year old woman presented with a five month history of pain of the mid-lumbar spine that had confined her to bed. Her other medical history was unremarkable. She experienced intense pain on - turning in, or getting out of, bed. There was no spinal tenderness. Straight leg raising was full without neurological deficit.

$X$ Ray films showed generalised osteoporosis and a crush fracture of L3. A bone scan showed multiple sites of increased uptake throughout the spine. All blood tests, including liver function tests, gave normal results. Urinary calcium excretion was normal. Immunoelectrophoresis showed suppressed immunoglobulin concentrations: IgG $4 \cdot 1 \mathrm{~g} / \mathrm{l}, \mathrm{IgA}<0 \cdot 5 \mathrm{~g} / \mathrm{l}, \mathrm{IgM}$ $<0.3 \mathrm{~g} / \mathrm{l}$. No serum paraprotein was ever identified. Immunoelectrophoresis of urine gave a positive result for Bence Jones protein on one occasion, but this was not confirmed in two further urine specimens. A trephine biopsy of the iliac crest showed that the marrow contained $30 \%$ plasma cells, including many abnormal forms. Immunohistochemical examination identified $x$ light chains produced by plasma cells.

Multiple myeloma was diagnosed, and she was treated with radiotherapy, melphalan, and prednisolone with satisfactory relief of pain.

\section{Comment}

Over a third of women aged over 65 suffer osteoporotic vertebral fractures.' Underlying diseases such as multiple myeloma or an endocrine disorder predisposing to osteoporosis should be sought as specific treatment may prevent further loss of bone.
Diffuse osteoporosis is the predominant radiological feature in only $6 \%$ of cases of myeloma. ' This loss of bone is attributed to production of lymphokine. ${ }^{3}$ Myeloma characteristically presents with osteolytic bone lesions and secretion of a monoclonal immunoglobulin with or without Bence Jones proteinuria. An associated hypogammaglobulinaemia is found in 9\% of patients.' Our patients had "non-secretory" myeloma, a recognised subtype, in which no detectable paraprotein is found on electrophoresis of serum and urine. It occurs in $4 \%$ of all cases of myeloma. ${ }^{2}$ Reduced immunoglobulin concentrations were a constant feature in one subgroup of patients in a study, who were also characterised by bone loss and normal serum calcium concentrations and renal function. Two out of seven patients in this group had generalised osteoporosis. $^{+}$Our two patients may be further examples of this pattern.

Underlying disease should always be considered in patients with apparently "simple" osteoporosis. Immunoelectrophoresis should be performed in all patients but may miss myeloma. If serum immunoglobulin concentrations are reduced in the absence of other evidence of myeloma bone marrow aspiration should be performed.

1 Riggs BL, Melton LJ. Involutional osteoporosis. N Engl f Med 1986;314: 1676-86.

2 Kyle RA. Multiple myeloma-review of 869 cases. Mayo Clin Proc 1975;50:29-40.

3 Garrett IR, Durie BGM, Nedwin GE, et al. Production of lymphotoxin, a bone resorbing cytokine, by cultured human myeloma cells. $N$ Engl f Med 1987;317:526-32

4 Cavo M, Galieni P, Gobbi M, et al. Nonsecretory multiple myeloma. Acta Haematol (Basel) 1985;74:27-30.

(Accepted 14 fune 1989)

\title{
Cost analysis of prophylaxis with antibiotics to prevent infected knee arthroplasty
}

\section{Sten Bengtson, Lars Borgquist, Lars Lidgren}

\section{Department of}

Orthopaedics, University

of Lund, S-221 85 Lund,

Sweden

Sten Bengtson, MD, senior registrar

Lars Lidgren, MD, professor of orthopaedics

\section{Department of Health and Society, Linköping University, S-581 85 Linköping, Sweden \\ Lars Borgquist, $\mathrm{MD}$, associate professor}

\section{Correspondence to: Dr Bengtson.}

Br Med f 1989;299:719-20
Infection after a knee arthroplasty can be disastrous to the patient and puts a heavy economic burden on society. We studied the direct medical costs of infected knee arthroplasties and analysed the cost effectiveness of prophylaxis with antibiotics in patients with knee arthroplasties and concomitant skin lesions.

\section{Patients, methods, and results}

Thirty two of 1047 knee arthroplasties performed at our hospital between 1970 and 1985 became infected.' There were 17 haematogenous infections, and the most common distant focuses were skin ulcers and vasculitic lesions (six cases).

We calculated the direct medical costs for normal and infected knee arthroplasties from the costs of the operation, the number of days in hospital, outpatient visits, radiological examinations, and antibiotic treatment. We used the price lists of the regional hospital and of the National Corporation of Swedish Pharmacies for $1988(£ 1=$ Swedish $\mathrm{kr} 11 \cdot 20)$. The total direct costs averaged kr 353951 ( $\$ 31603)$ for a patient with infection (range kr 77 464-692952 (£6916-61 871)) and $\mathrm{kr} 47868$ (£4274) for a patient without infection (table).

Ainscow and Denham reported three cases of haematogenous infection among 40 cases of recurrent skin ulceration and infection. ${ }^{2}$ By extrapolation to our study, our six cases of haematogenous infection would have occurred among 80 cases of recurrent skin ulceration and infection. We assumed that these haematogenous infections could be avoided by prophylactic treatment with antibiotics, and we calculated the cost saved per infection prevented by the formula $\left(\mathrm{C}_{\text {inf }} \times \mathrm{SI}-\left(\mathrm{C}_{\mathrm{ab}}+\mathrm{C}_{\mathrm{se}}\right)\right) / \mathrm{SI}$, where $\mathrm{C}_{\mathrm{inf}}=$ additional costs in cases of infection, $\mathrm{SI}=$ number of infections prevented, $\mathrm{C}_{\mathrm{ab}}=$ costs of prophylaxis, and $\mathrm{C}_{\mathrm{se}}=$ costs of side effects of prophylaxis.

Thus $\mathrm{C}_{\text {inf }}=$ cost per case of infection minus cost per case without infection $=\mathrm{kr}$ 353951-47868 $(£ 31603-4274)=k r 306083(£ 27329)$. From previous studies' we assumed the effectiveness of antibiotics to be $85 \%$; thus $\mathrm{SI}=0 \cdot 85 \times 6=5 \cdot 1$. We assumed that each patient would take prophylaxis of $3 \mathrm{~g}$ daily for one year; thus $\mathrm{C}_{\mathrm{ab}}$ for 80 patients $=\mathrm{kr} 864000(£ 77143)$ for flucloxacillin $(3 \times \mathrm{kr} \quad 10 \times 360 \times 80)$ and $\mathrm{kr} 950400$ $(£ 84857)$ for cephalexin $(3 \times \mathrm{kr} 11 \times 360 \times 80)$. The

Direct medical costs (Swedish kronas) of treatment for patients with and without infection after knee arthroplasty, Sweden, 1988

\begin{tabular}{|c|c|c|c|c|c|c|c|c|c|c|c|}
\hline & \multicolumn{2}{|c|}{ Operations } & \multicolumn{2}{|c|}{$\begin{array}{l}\text { Days in } \\
\text { hospital }\end{array}$} & \multicolumn{2}{|c|}{$\begin{array}{c}\text { Visits as } \\
\text { outpatient }\end{array}$} & \multicolumn{2}{|c|}{$\begin{array}{l}\text { Radiographic } \\
\text { examinations }\end{array}$} & \multicolumn{2}{|c|}{$\begin{array}{c}\text { Days of antibiotic } \\
\text { treatment }\end{array}$} & \multirow{2}{*}{$\begin{array}{l}\text { Total } \\
\text { cost } \\
(\mathrm{kr})\end{array}$} \\
\hline & $\begin{array}{l}\text { Mean } \\
\text { No }\end{array}$ & $\begin{array}{l}\text { Cost } \\
(\mathrm{kr})\end{array}$ & $\begin{array}{c}\text { Mean } \\
\text { No }\end{array}$ & $\begin{array}{l}\text { Cost } \\
(\mathrm{kr})\end{array}$ & $\begin{array}{c}\text { Mean } \\
\text { No }\end{array}$ & $\begin{array}{l}\text { Cost } \\
(\mathrm{kr})\end{array}$ & $\begin{array}{c}\text { Mean } \\
\text { No }\end{array}$ & $\begin{array}{l}\text { Cost } \\
(\mathrm{kr})\end{array}$ & $\begin{array}{l}\text { Mean } \\
\text { No }\end{array}$ & $\begin{array}{l}\text { Cost } \\
(\mathrm{kr})\end{array}$ & \\
\hline Patients without infection & 1 & 26526 & 14 & 18312 & 3 & 1305 & 3 & 1260 & 14 & 465 & 47868 \\
\hline Patients with infection & $3 \cdot 3$ & 74962 & 145 & 243384 & 16 & 7227 & 12 & 5392 & 1328 & $27201^{\prime}$ & 353951 \\
\hline
\end{tabular}


reported number of serious side effects per million defined daily doses (taken as $2 \mathrm{~g}$ for these drugs) is 0.8 for flucloxacillin and 3.4 for cephalexin (extracted from records of the Swedish adverse drug reactions advisory committee, Uppsala, Sweden, 1989). Thus in our analysis the number of serious side effects was 0.03 and 0.15 respectively, the number of defined daily doses being $43200(80 \times 3 \times 360 / 2)$. Pseudomembranous colitis is the single most common serious side effect. The average number of days in hospital for patients with diarrhoea induced by antibiotics was four at the department of infectious diseases in Lund in 1987. Thus $\mathrm{C}_{\mathrm{se}}=\mathrm{kr} 276$ (£25) for flucloxacillin $(0.03 \times \mathrm{kr} 2300(£ 205)$ per hospital day $\times 4$ hospital days) and $\mathrm{kr} 1380$ (£123) for cephalexin $(0 \cdot 15 \times \mathrm{kr} 2300$ $(£ 205) \times 4)$.

Thus the cost saved per infection prevented is kr 119459 ( $£ 10666)$ with flucloxacillin and kr 136617 (£12 198) with cephalexin.

\section{Comment}

We were unable to assess accurately the cost of many things that are more likely to be a burden to patients with infection - for example, transportation, technical aids, staying in a nursing home, and laboratory tests. Indirect costs such as the costs of sick leave and early retirement may be similar to direct costs for patients with rheumatoid arthritis and arthrosis.. ${ }^{3}$ Thus we certainly underestimated the costs of treatment for a patient with infection.

The cost saved per infection prevented is probably higher than that calculated here as we arbitrarily set the duration of prophylaxis at one year. Most wounds will be operated on and should then heal within a few months.

Twelve thousand knee arthroplasties were performed in Sweden ( $8 \cdot 3$ million inhabitants) during 1975-85. Eighty nine of the patients developed haematogenous infection, which in 28 cases originated from skin lesions (unpublished data). If $85 \%$ of these 28 infections could have been prevented $\mathrm{kr} 3251485$ ( $£ 290312$ ) would have been saved.

Infected knee arthroplasty is an important problem medically as well as economically. To prevent haematogenous infections prophylactic antibiotic treatment should be given to patients with skin ulcers until these have healed.

We thank Lund County Council, Trygg-Hansa, and Alfred Österlund's Foundation for grants.

1 Bengtson S, Knutson K, Lidgren L. Treatment of the infected knee arthroplasty. Clin Orthop (in press).

Ainscow DA, Denham RA. The risk of hematogenous infection in total joint replacement. Clin Orthop 1978;137:69-75.

3 Liang MH, Larson M,. Thompson M, et al. Costs and outcomes in rheumatoid arthritis and osteo-arthritis. Arthritis Rheum 1984;27:522-9.

(Accepted 26 fune 1989)

\section{Slipped upper femoral epiphysis in an amenorrhoeic athlete}

\section{R L Wolman, M G Harries, I Fyfe}

Northwick Park Hospital, Harrow, Middlesex HA1 3UJ

R L Wolman, MRCP, registrar, British Olympic Medical Centre

M G Harries, MRCP, director, British Olympic Medical Centre

I Fyfe, FRCs, consultant orthopaedic surgeon

Correspondence to: $\mathrm{Dr}$ Wolman.

BrMed f 1989;299:720-1
Delay in the menarche is a recognised feature of endurance training. We report on a 17 year old runner with primary amenorrhoea who had a slipped upper femoral epiphysis.

\section{Case report}

A 17 year old girl presented to the sports injuries clinic with a nine month history of pain in the right thigh. She was a middle distance runner of county standard and as part of her training ran $64 \mathrm{~km}$ each week. She had been training since the age of 10 . The pain had started gradually and had not been associated with any injury but was aggravated by exercise and prevented her from doing intensive training. She had been treated with physiotherapy, but this

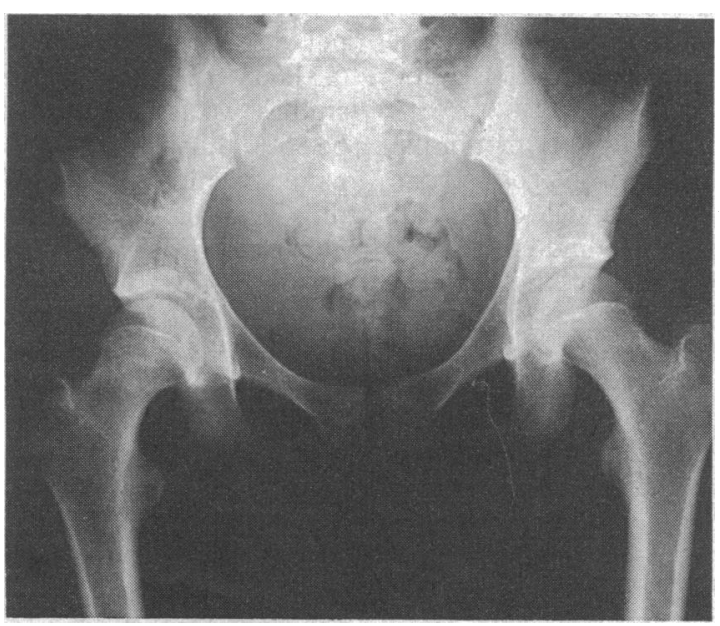

had made little difference to her symptoms. She also had primary amenorrhoea, which was thought to be related to her training.

Examination showed a physically immature 17 year old girl. Her hips and back were normal. An $x$ ray film of the pelvis showed partial slipping of the right femoral epiphysis (figure). She was admitted to hospital, where internal fixation was performed. She made a good postoperative recovery and was advised to stop training for the next year to allow the epiphysis to close.

Before the operation her bone age was $14 \cdot 1$ years (revised method of Tanner and Whitehouse, 1975) and her physical maturity was Tanner stage $3 / 4$ (that is, peripubertal). Her body fat was only $15 \cdot 3 \%$ (by the established method of Durnin and Womersley, 1974), compared with a normal range of $20-30 \%$. When she returned to the clinic after two months' rest from training her body fat had increased to $16.7 \%$, menarche had occurred, and an $x$ ray film confirmed that the femoral epiphysis was closing.

\section{Comment}

A slipped upper femoral epiphysis tends to occur in young adolescents, with an incidence of two cases per $100000 .{ }^{1}$ It is more common in boys (ratio 3:1) and is probably an important cause of osteoarthritis in later life. ${ }^{12}$ It is a prepubertal disorder and is associated with various endocrine disorders including hypothyroidism, panhypopituitarism, and hypogonadism. 'It is unusual in girls over the age of 14 . In this case the pubertal delay caused by intensive training resulted in retarded maturation of bone. The consequent delayed closure of the femoral epiphysis increased the period in which the slip could occur. Furthermore, intense physical activity may have increased the shearing forces placed on the hip and so increased the risk still further. ${ }^{2}$

Menarche tends to occur later in athletes than in the general population. ${ }^{3}$ This reflects generalised pubertal delay and is related to the intensity of training and associated low levels of body fat. Frisch and McArthur estimated that body fat must reach a level of 